\title{
Insulin-like growth factor and growth hormone receptor in postpartum lactating beef cows
}

\author{
Augusto Schneider ${ }^{(1)}$, Luiz Francisco Machado Pfeifer(2), Lucas Teixeira Hax ${ }^{(2)}$, Giane Regina Paludo(3), \\ Francisco Augusto Burkert Del Pino(4), Nelson José Laurino Dionello(5) and Marcio Nunes Corrêa(2)
}

\begin{abstract}
(1)Universidade Federal de Pelotas (Ufpel), Núcleo de Pesquisa, Ensino e Extensão em Pecuária, Centro de Biotecnologia, Campus Universitário, s/nº, CEP 96010-900 Pelotas, RS, Brazil. E-mail: augusto.schneider@live.com (2)Ufpel, Faculdade de Veterinária. E-mail: luizufpel@gmail. com, lucashax@hotmail.com, marcio.nunescorrea@gmail.com ${ }^{(3)}$ Universidade de Brasília, Faculdade de Veterinária, Campus Universitário Darcy Ribeiro, Asa Norte, CEP 70910-970 Brasília, DF, Brazil. E-mail: giane@unb.br (4)Ufpel, Departamento de Bioquímica. E-mail: fabdelpino@gmail.com ${ }^{(5)}$ Ufpel, Departamento de Zootecnia. E-mail: dionello@ufpel.edu.br
\end{abstract}

\begin{abstract}
The objective of this study was to evaluate the plasma concentrations of insulin-like growth factor-I (IGF-I), and the mRNA hepatic expression of IGF-I and of the growth hormone receptors GHR and GHR 1A, in postpartum beef cows. Four Angus and four crossbred (Angus $\mathrm{x}$ Nelore) postpartum suckled beef cows were used. Liver and blood samples were collected every 10 days, from calving to 40 days postpartum, for gene expression and for $\beta$-hydroxybutyrate and IGF-I assays, respectively. Samples for progesterone assay were collected every other day, from day 10 to 40 postpartum. Three cows ovulated before 40 days postpartum. IGF-I concentration was higher in Angus x Nelore than in Angus cows. There was no difference in the expression of GHR, GHR 1A and IGF-I according to breed or ovulatory status. IGF-I concentrations were higher in crossbred cows, but have not changed according to postpartum ovulatory status. Moreover, changes in postpartum IGF-I concentrations are not associated with changes in liver GHR, GHR 1A and IGF-I mRNA expression in either breed.
\end{abstract}

Index terms: Bos indicus, Bos taurus, GHR, IGF-I, mRNA hepatic expression, ovulation.

\section{Fator de crescimento semelhante à insulina e receptor do hormônio do crescimento no pós-parto de vacas de corte}

Resumo - O objetivo deste estudo foi avaliar as concentrações plasmáticas do fator de crescimento semelhante à insulina tipo I (IGF-I) e a expressão hepática de mRNA de IGF-I e dos receptores do hormônio de crescimento GHR e GHR 1A, no pós-parto de vacas de corte. Quatro vacas Angus e quatro mestiças (Angus x Nelore) lactantes foram usadas durante o período de pós-parto. As coletas de tecido hepático e de sangue foram realizadas a cada dez dias, do parto até 40 dias pós-parto, para a avaliação da expressão gênica, e análise de $\beta$-hidroxibutirato e IGF-I, respectivamente. As amostras para análise de progesterona foram coletadas a cada dois dias, dos dez aos 40 dias pós-parto. Três vacas ovularam antes dos 40 dias pós-parto. A concentração de IGF-I foi maior em vacas Angus x Nelore do que em vacas Angus. Não houve diferença na expressão hepática de GHR, GHR 1A e IGF-I de acordo com a raça ou com a ovulação. As concentrações de IGF-I foram maiores em vacas cruzadas, e não mudaram com o status ovulatório pós-parto. Além disso, as mudanças observadas na concentração de IGF-I, durante o período pós-parto, não estão associadas a alterações na expressão hepática de mRNA de GHR, GHR 1A e IGF-I, em nenhuma das duas raças.

Termos para indexação: Bos indicus, Bos taurus, GHR, IGF-I, expressão hepática de mRNA, ovulação.

\section{Introduction}

The main objective of cow-calf rearing is to produce one calf per cow annually. Although knowledge of cow reproductive biology has increased (Santos et al., 2004), factors involved in the resumption of postpartum cyclicity in cows are still unclear. During the peripartum period, the stress of pregnancy, parturition, onset of lactation and suckling negatively affect the energy intake (Ciccioli et al., 2003). This induces a postpartum negative energy balance, which is associated with a prolonged interval from calving to first ovulation (Stagg et al., 1998). However, the underlying cause of prolonged postpartum anestrus is not the lack of dominant follicle development (as follicular growth restarts during the first ten days after calving), but an ovulation failure (Diskin et al., 2003) due to reduced concentrations of metabolites that act

Pesq. agropec. bras., Brasília, v.45, n.8, p.925-931, ago. 2010 
directly on follicular growth and maturation (Beam \& Butler, 1999).

The growth hormone receptor (GHR), which modulates insulin-like growth factor I (IGF-I) synthesis under GH control (Jones \& Clemmons, 1995), is detected in higher abundance in the liver (Bornfeldt et al., 1989). The three most expressed liver variants are GHR 1A, GHR 1B and GHR 1C, responsible for 50, 35 and $15 \%$ of the total GHR mRNA, respectively (Jiang \& Lucy, 2001). Although during the early postpartum period, there is a simultaneous reduction in GHR $1 \mathrm{~A}$ and IGF-I mRNA expression in the liver of dairy cows due to intense negative energy balance (Radcliff et al., 2003a), no similar condition was observed for beef cows (Jiang et al., 2005). The reduced expression of these genes in liver led to reduced plasma IGF-I concentration, which is restored about three weeks postpartum due to decreasing intensity of the negative energy balance (Kobayashi et al., 1999).

Apparently, the GH/IGF-I axis is also involved in the mechanisms of resumption of the postpartum cyclicity, since plasma concentrations of IGF-I, during the postpartum period increased linearly up to the day of first ovulation (Stagg et al., 1998) and correlated with the length of anestrus in beef cows (Roberts et al., 2005). In addition, according to Spicer et al. (2002) IGF-I concentration increased more in Angus $\mathrm{x}$ Brahman than Angus cows in the early postpartum period. Alvarez et al. (2000) showed that Brahman cows had greater plasma IGF-I concentration than Angus cows during the entire postpartum period. The IGF-I acts on the ovary via the type-1 IGF receptor (Willis et al., 1998) and functions as a modulator of gonadotrophin action, stimulating granulosa and theca cell proliferation and differentiation (Armstrong \& Webb, 1997) and preventing follicular atresia (el-Roeiy et al., 1994).

Considering these evidences, it is important to evaluate if the increasing IGF-I concentrations in postpartum beef cattle are associated with higher hepatic expression of GHR/GHR1A/IGF-I mRNA; if increased plasma IGF-I concentration and expression of GHR/GHR1A/IGF-I mRNA in the liver are associated with early resumption of ovulation; and if expression of GHR/GHR 1A/IGF-I mRNA during postpartum is higher in crossbred than in Bos taurus cattle.

The objective of this study was to evaluate the plasma concentrations of the insulin-like growth
factor-I (IGF-I) and the mRNA hepatic expression of IGF-I and of the growth hormone receptors GHR and GHR 1A, in postpartum beef cows.

\section{Materials and Methods}

The Comitê de Ética na Experimentação Animal, from the Universidade Federal de Pelotas, has approved all procedures performed in this experiment (Protocol 23110.004382/2010-89).

The experiment was carried out in a farm located at $30^{\circ} 36{ }^{\prime} \mathrm{S}, 51^{\circ} 21^{\prime} \mathrm{W}$ and $6 \mathrm{~m}$ altitude, in southern Brazil. Eight postpartum suckled beef cows, four Angus (Bos taurus) and four crossbred cows [Angus $\mathrm{x}$ Nelore (Bos taurus x Bos indicus)] were used. All the parturitions occurred in a three-day interval and the calving day was considered day 0 . The cows had a mean body condition score of $2.81 \pm 0.26$, ranging from 2.5-3.0, (Lowman et al., 1976), at the beginning of the experiment, and were maintained in a native pasture.

Blood samples were collected from coccygeal vein into heparinized $10-\mathrm{mL}$ vacutainer tubes (BD Diagnostics, São Paulo, Brazil). The tubes were immediately centrifuged $(1,500 \mathrm{~g}$ for $15 \mathrm{~min})$, and the plasma was collected and stored at $-80^{\circ} \mathrm{C}$ until evaluation. Samples were collected every two days for progesterone analyses, from day ten to 40 , and every ten days, from day 0 to 40 , for IGF-I and $\beta$-hydroxybutyrate analyses, respectively.

The $\beta$-hydroxybutyrate assays were performed in a single batch. Beta-hydroxybutyrate Ranbut, (Randox, Crumlin, United Kingdom) concentration was evaluated through final point of enzymatic colorimetric reactions, quantified by a spectrophotometer, FEMTO 700 Plus (Femto Ind. e Com. de Instrumentos Ltda., São Paulo, Brazil) (Velazquez et al., 2005). The detection limit of the assay was $1.04 \mathrm{mg} \mathrm{dL}^{-1}$, and the intra-assay coefficient of variation was $3.7 \%$.

The progesterone assays were performed in a single batch. Progesterone concentrations were measured using electrochemiluminescence immunoassay Elecsys 2010, (Roche Diagnostics, Basel, Switzerland) and Progesterone II kits (Roche Diagnostics, Manheim, USA) (Bargouli et al., 2007). The detection limit of the assay was $0.03 \mathrm{ng} \mathrm{mL}^{-1}$, and the intra-assay coefficient of variation was $5.4 \%$. A cow was considered ovulated when the blood concentration of progesterone rose above $1 \mathrm{ng} \mathrm{mL}^{-1}$ in two consecutive samples (Stevenson 
$\&$ Britt, 1979). Three cows (one Angus and two Angus $\mathrm{x}$ Nelore) ovulated before 40 days postpartum (mean $36.3 \pm 0.3$ days), and were considered as the ovulatory group $(\mathrm{Ov})$. The other five cows did not ovulate in this period and were considered as the nonovulatory group (Nov).

Plasma IGF-I concentrations were evaluated by radioimmunoassay DSL-5600 (Diagnostics Systems Laboratory, Webster, USA) (Awawdeh et al., 2004), after an extraction step in which IGF-I was separated from its binding proteins, and had a minimum detection limit of $2.25 \mathrm{ng} \mathrm{mL}^{-1}$. The intra-assay coefficients of variation were 5.14 and $9.15 \%$, for low and high IGF-I concentrations, respectively. The inter-assay coefficients of variation were 1.06 and $0.66 \%$, for low and high IGF-I concentrations, respectively.

On the same days of the blood sample collections (days 0, 10, 20, 30 and 40), transcutaneous liver biopsies were performed according to Radcliff et al. (2003a). The liver samples were immediately stored in microtubes and frozen in liquid nitrogen until RNA extraction.

Total RNA was extracted using Trizol (Invitrogen, Carlsbad, USA), according to the manufacturer's instructions. The RNA quality was evaluated by calculating the ratio of absorbance at 260 and $280 \mathrm{~nm}$, followed by electrophoresis on a $1.5 \%$ agarose gel stained with etidium bromide. Only RNA with intact $18 \mathrm{~S}$ and $28 \mathrm{~S}$ bands were used.

Total RNA was treated with DNAse I DNAse Amp Grade, (Invitrogen, Carlsbad, USA), in order to remove genomic DNA contamination, and was primed with oligo(dT)20 to synthesize single strand cDNA SuperScript III First-Strand Synthesis Supermix, (Invitrogen, Carlsbad, USA). The polymerase chain reaction (PCR) amplifications and fluorescence detection, using the cDNA obtained in the previous step, were performed in duplicate in the ABI Prism 7500 Sequence Detection System (Applied Biosystems, Foster City, USA), using the SYBR Green detection chemistry Platinum SYBR Green qPCR SuperMix-UDG kit, (Invitrogen, Carlsbad, USA) as recommended by the manufacturer. The primer sequences were as follows: GHR (forward CCA GTT TCC ATG GTT CTT AAT TAT; reverse TTC CTT TAA TCT TTG GAA CTG G) (Pfaffl et al., 2002); GHR 1A (forward AGC GAC ATT ACA CCA GCA GGA A; reverse AGG GGC CAG GGC AAT GTA CTT TT);
IGF-I (forward TCG CAT CTC TTC TAT CTG GCC CTG T; reverse GCA GTA CAT CTC CAG CCT CCT CAG A) (Pfaffl et al., 2002) and $\beta$-actin (forward CTA GGC ACC AGG GCG TCA TG; reverse CTT AGG GTT CAG GGG GGC CT).

The PCR reaction efficiencies and cycle thresholds from the fluorescence readings of individual wells, during the reaction, were calculated using PCR Miner (Sheng \& Russell, 2005). For each sample, a mean cycle threshold of two PCR reactions was calculated. Also, the expression of each target gene of interest was calculated relatively to $\beta$-actin, using the equation: relative target gene expression $=\left(1 / \mathrm{E}_{\text {target }}{ }^{\mathrm{CTtarget}}\right) /$ $\left(1 / \mathrm{E}_{\beta \text {-actin }}{ }^{\text {CT-actin }}\right)$, where $\mathrm{E}$ was reaction efficiency and CT was cycle threshold (Cikos \& Koppel, 2009). The mean coefficient of variation among sample CTs was $0.71 \%$. The specificity of each primer was verified by the detection of only one fluorescence peak at the dissociation curve for each replicate at the end of the PCR.

The statistical analyses were performed in SAS (SAS Institute, 2002). The effects of age, parity, body condition score, and body weight had no effects in the model; therefore, they were excluded from the final statistical model. Analyses involving repeated measures over time were compared between breed and ovulatory status, by analysis of variance for repeated measures, using the mixed procedure to evaluate the main effects of breed, ovulatory status, day and their interactions. When no effects of ovulatory status and breed over time were detected, these factors were removed from the model. Pearson's correlations were also determined. The analyses were carried out at 5\% probability.

\section{Results and Discussion}

The most important observation of this study was the marked increase in plasmatic IGF-I concentration in postpartum crossbred cows Angus x Nelore, in comparison to Angus cows, despite no difference in the hepatic expression of GHR/IGF-I mRNA. In addition, no changes in the concentration of IGF-I or GHR/IGF-I mRNA expression were observed between ovulatory and nonovulatory cows.

There was no effect of days postpartum, ovulatory group, breed and their interactions on $\beta$-hydroxybutyrate concentrations (Table 1 ). There was 
also no effect of days postpartum or ovulatory group on IGF-I concentration. However, there were significant effects of breed (and breed-by-ovulation interaction) on IGF-I plasma concentration. IGF-I concentration was higher in crossbred cows (Angus $\mathrm{x}$ Nelore, $\left.53.8 \pm 4.6 \mathrm{ng} \mathrm{mL}^{-1}\right)$ than inAngus cows $\left(39.8 \pm 1.5 \mathrm{ng} \mathrm{mL}^{-1}\right)$ during the study period. In fact, IGF-I concentration was lower in both Ov and Nov Angus cows (42.4 \pm 7.5 and 38.6 $\pm 5.1 \mathrm{ng} \mathrm{mL}^{-1}$, respectively) when compared to $\mathrm{Ov}$ and Nov crossbred cows $(50.6 \pm 20.5$ and $57.0 \pm 13.7 \mathrm{ng} \mathrm{mL}^{-1}$, respectively). In addition, there were no differences in the $\beta$-hydroxybutyrate $\left(7.9 \pm 1.3\right.$ vs. $\left.5.9 \pm 1.4 \mathrm{mg} \mathrm{dL}^{-1}\right)$ and IGF-I $(44.8 \pm 3.8$ vs. $59.0 \pm 25.8 \mathrm{ng} \mathrm{mL}^{-1}$ ) concentrations before and after ovulation for cows of the Ov group.

The higher IGF-I concentration in crossbred compared to Angus cows observed in this study is consistent with previous observations (Alvarez et al., 2000). In addition, the increase of this hormone concentration was more evident at day 40 postpartum. Similarly, Spicer et al. (2002) observed a rise in IGF-I concentration from weeks two to seven postpartum in Brahman x Angus cows, but not in Angus cows. The difference between the two breeds may be due to different lactational demand, since Nelore cows produce less milk than Angus cows (Jenkins et al., 2000), and there is a negative association between potential for milk production and circulating IGF-I concentration (Roberts et al., 2005).

Although differences between breeds were detected, plasmatic IGF-I concentration dit not change between Ov and Nov groups. However, previous data indicate that IGF-I was higher in both dairy (Kawashima et al., 2007) and beef cows (Kawashima et al., 2008) that ovulated earlier in the postpartum. Moreover, $\beta$-hydroxybutyrate concentration did not change between Ov and Nov groups in the current study, in agreement with results from Kawashima et al. (2008) in beef cattle, despite the observation by Taylor et al. (2003) that dairy cows with delayed ovulation have higher $\beta$-hydroxybutyrate levels. Furthermore, there were no changes in the IGF-I and $\beta$-hydroxybutyrate concentrations before and after ovulation in the $\mathrm{Ov}$ group, contrasting with results from Kawashima et al. (2007), who observed a reduction in IGF-I concentrations after ovulation in postpartum dairy cows.

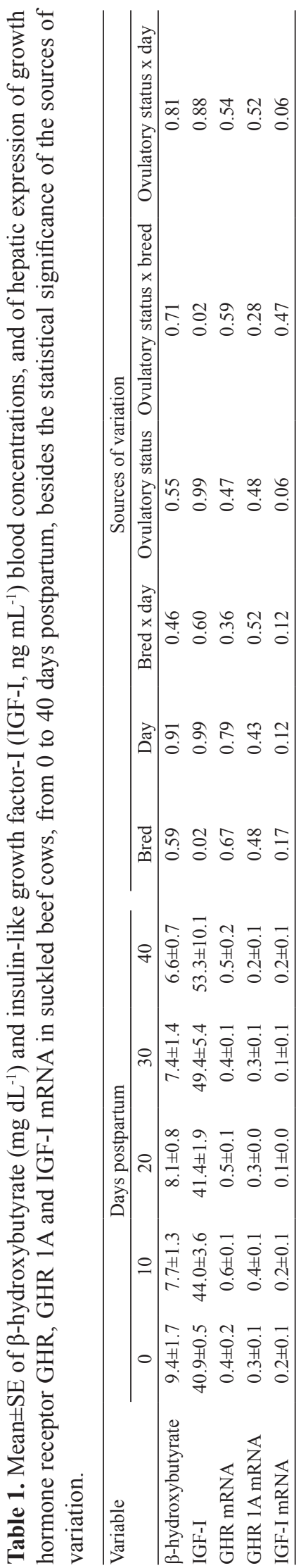


Hepatic expression of GHR, GHR 1A and IGF-I mRNA did not change from day 0 to 40 postpartum (Table 1), as previously observed by Jiang et al. (2005), in Angus cows at the prepartum, partum and early postpartum period, using ribonuclease protection assay. These data are contradictory with results from studies with Holstein cows, which had a simultaneous reduction in hepatic GHR 1A and IGF-I mRNA in the early postpartum period (Radcliff et al., 2003b), probably because dairy cows undergo a more severe negative energy balance at this period (Fenwick et al., 2008). Although an interaction between ovulation and day for IGF-I mRNA expression was detected, no differences within days were observed. No difference was detected in the expression of GHR $(0.46 \pm 0.06$ x $0.48 \pm 0.17)$, GHR $1 \mathrm{~A}(0.29 \pm 0.04 \times 0.23 \pm 0.06)$ and IGF-I $(0.18 \pm 0.03 \times 0.19 \pm 0.06)$ mRNA, when the periods before and after ovulation were compared in the three cows that ovulated (Ov Group). However, Rhoads et al. (2008) observed that there was no correlation between hepatic and ovarian expression of GHR or IGF-I mRNA in postpartum dairy cows, and that the hypothesis that this gene is differentially regulated in the ovary of ovulatory cows could not be dismissed.

Plasma concentrations of IGF-I were not correlated with hepatic expression of its gene in the present study, contrasting with previous observations in dairy cows (Fenwick et al., 2008). Moreover, despite the higher plasmatic concentration of IGF-I in crossbred cows, hepatic IGF-I mRNA expression did not follow the same pattern. This contradiction could be due to the fact that plasmatic concentration of IGF-I is also correlated to the hepatic expression of IGF binding proteins 1-6 and to the IGF acid labile subunit (IGF ALS) (Fenwick et al., 2008), which regulates IGF-I plasma half-life and transport through the vascular endothelium (Thissen et al., 1994). Moreover, the decreased concentration of IGF-I in postpartum beef cows coincided with an increased concentration of circulating IGFBP-2 and decreased IGFBP-3 (Roberts et al., 1997). Therefore, more studies with a higher number of cows and considering the various intermediate steps of the somatotropic axis must be done, in order to explain the source of serum IGF-I reduction in beef cattle.

A positive correlation between hepatic GHR and GHR 1A mRNA expression was observed $(n=24$, $\mathrm{r}=0.81, \mathrm{p}<0.0001)$. However, no correlation between
GHR and IGF-I mRNA or GHR 1A and IGF-I mRNA was observed, except for crossbred cows, which had a positive correlation between GHR $1 \mathrm{~A}$ and IGF-I mRNA ( $r=0.55, p=0.02)$. This overall absence of correlation between GHR, GHR 1A and IGF-I mRNA was in agreement with previous data for dairy cattle (Butler et al., 2003). Although in this last study, no correlation had been found between hepatic expression of GHR, GHR 1A and IGF-I mRNA in control cows, a positive correlation between GHR $1 \mathrm{~A}$ and IGF-I mRNA was observed in cows treated with insulin. Similarly, in the current study, a positive correlation was only observed between GHR $1 \mathrm{~A}$ and IGF-I mRNA in crossbred cows. This observation may be linked to higher plasmatic concentration of IGF-I, as a consequence of different lactational demand and negative energy balance intensity, resembling the condition in the study of Butler et al. (2003), in which insulin infusion induced a positive correlation between hepatic GHR 1A and IGF-I mRNA.

\section{Conclusions}

1. Concentrations of IGF-I are higher in Angus $x$ Nelore crossbred cows than in Angus ones, but do not change with postpartum ovulatory status.

2. Changes in postpartum serum IGF-I concentrations are not associated to liver GHR, GHR 1A and IGF-I mRNA expression in Angus and Angus $x$ Nelore suckled beef cows.

\section{Acknowledgements}

To Coordenadoria de Aperfeiçoamento de Pessoal de Nível Superior and Conselho de Desenvolviemtno Científico e Tecnológico, for the financial support; to Drs. Daniel Melo and Joaquim Melo, who provided cattle and farm facilities; to Drs. Pericles Duarte and José Wilson da Silva Neto, for help with data collection; and to Dr. Jerri Zanuso, for the effort to provide funds to support this study.

\section{References}

ALVAREZ, P.; SPICER, L.J.; CHASE JUNIOR, C.C.; PAYTON, M.E.; HAMILTON, T.D.; STEWART, R.E.; HAMMOND, A.C.; OLSON, T.A.; WETTEMANN, R.P. Ovarian and endocrine characteristics during an estrous cycle in Angus, Brahman, and Senepol cows in a subtropical environment. Journal of Animal Science, v.78, p.1291-1302, 2000. 
ARMSTRONG, D.G.; WEBB, R. Ovarian follicular dominance: the role of intraovarian growth factors and novel proteins. Reviews in Reproduction, v.2, p.139-146, 1997.

AWAWDEH, M.S.; TITGEMEYER, E.C.; MCCUISTION, K.C.; GNAD, D.P. Effects of ammonia load on methionine utilization by growing steers. Journal of Animal Science, v.82, p.3537-3542, 2004.

BARGOULI, G.G.; TSANTARLIOTOU, M.P.; BROZOS, C.N.; KOKOLIS, N.A.; BOSCOS, C.M. Effect of norgestomet treatment on plasminogen activator activity in the cervical mucus and the endometrium in dairy cows. Journal of Veterinary Medicine, Series A. Physiology, Pathology and Clinical Medicine, v.54, p.393-397, 2007.

BEAM, S.W.; BUTLER, W.R. Effects of energy balance on follicular development and first ovulation in postpartum dairy cows. Journal of Reproduction and Fertility, v.54, p.411-424, 1999.

BORNFELDT, K.E.; ARNQVIST, H.J.; ENBERG, B.; MATHEWS, L.S.; NORSTEDT, G. Regulation of insulin-like growth factor-I and growth hormone receptor gene expression by diabetes and nutritional state in rat tissues. Journal of Endocrinology, v.122, p.651-656, 1989.

BUTLER, S.T.; MARR, A.L.; PELTON, S.H.; RADCLIFF, R.P.; LUCY, M.C.; BUTLER, W.R. Insulin restores GH responsiveness during lactation-induced negative energy balance in dairy cattle: effects on expression of IGF-I and GH receptor 1A. Journal of Endocrinology, v.176, p.205-217, 2003.

CICCIOLI, N.H.; WETTEMANN, R.P.; SPICER, L.J.; LENTS, C.A.; WHITE, F.J.; KEISLER, D.H. Influence of body condition at calving and postpartum nutrition on endocrine function and reproductive performance of primiparous beef cows. Journal of Animal Science, v.81, p.3107-3120, 2003.

CIKOS, S.; KOPPEL, J. Transformation of real-time PCR fluorescence data to target gene quantity. Analytical Biochemistry, v.384, p.1-10, 2009.

DISKIN, M.G.; MACKEY, D.R.; ROCHE, J.F.; SREENAN, J.M. Effects of nutrition and metabolic status on circulating hormones and ovarian follicle development in cattle. Animal Reproduction Science, v.78, p.345-370, 2003

EL-ROEIY, A.; CHEN, X.; ROBERTS, V.J.; SHIMASAKAI, S.; LING, N.; LEROITH, D.; ROBERTS JUNIOR, C.T.; YEN, S.S. Expression of the genes encoding the insulin-like growth factors (IGF-I and II), the IGF and insulin receptors, and IGF-binding proteins-1-6 and the localization of their gene products in normal and polycystic ovary syndrome ovaries. Journal of Clinical Endocrinology and Metabolism, v.78, p.1488-1496, 1994.

FENWICK, M.A.; FITZPATRICK, R.; KENNY, D.A.; DISKIN, M.G.; PATTON, J.; MURPHY, J.J.; WATHES, D.C. Interrelationships between negative energy balance (NEB) and IGF regulation in liver of lactating dairy cows. Domestic Animal Endocrinology, v.34, p.31-44, 2008.

JENKINS, T.G.; FERRELL, C.L.; ROBERTS, A.J. Lactation and calf weight traits of mature crossbred cows fed varying daily levels of metabolizable energy. Journal of Animal Science, v.78, p.7-14, 2000 .
JIANG, H.; LUCY, M.C. Variants of the 5'-untranslated region of the bovine growth hormone receptor mRNA: isolation, expression and effects on translational efficiency. Gene, v.265, p.45-53, 2001.

JIANG, H.; LUCY, M.C.; CROOKER, B.A.; BEAL, W.E. Expression of growth hormone receptor 1A mRNA is decreased in dairy cows but not in beef cows at parturition. Journal of Dairy Science, v.88, p.1370-1377, 2005.

JONES, J.I.; CLEMMONS, D.R. Insulin-like growth factors and their binding proteins: biological actions. Endocrine Reviews, v.16, p.3-34, 1995

KAWASHIMA, C.; FUKIHARA, S.; MAEDA, M.; KANEKO, E.; MONTOYA, C.A.; MATSUI, M.; SHIMIZU, T.; MATSUNAGA, N.; KIDA, K.; MIYAKE, Y.; SCHAMS, D.; MIYAMOTO, A. Relationship between metabolic hormones and ovulation of dominant follicle during the first follicular wave post-partum in high-producing dairy cows. Reproduction, v.133, p.155-163, 2007.

KAWASHIMA, C.; KIDA, K.; MATSUHASHI, M.; MATSUI, M.; SHIMIZU, T.; MATSUNAGA, N.; ISHII, M.; MIYAKE, Y.; MIYAMOTO, A. Effect of suckling on the reproductive performance and metabolic status of obese Japanese black cattle during the early postpartum period. Journal of Reproduction and Development, v.54, p.46-51, 2008.

KOBAYASHI, Y.; BOYD, C.K.; BRACKEN, C.J.; LAMBERSON, W.R.; KEISLER, D.H.; LUCY, M.C. Reduced growth hormone receptor (GHR) messenger ribonucleic acid in liver of periparturient cattle is caused by a specific down-regulation of GHR 1A that is associated with decreased insulin-like growth factor I. Endocrinology, v.140, p.3947-3954, 1999.

LOWMAN, B.G.; SCOTT, N.A.; SOMERVILLE, S.H. Condition scoring of cattle. Edinburgh: Edinburgh School of Agriculture, 1976. 31p.

PFAFFL, M.W.; GEORGIEVA, T.M.; GEORGIEV, I.P.; ONTSOUKA, E.; HAGELEIT, M.; BLUM, J.W. Real-time RT-PCR quantification of insulin-like growth factor (IGF)-1, IGF-1 receptor, IGF-2, IGF-2 receptor, insulin receptor, growth hormone receptor, IGF-binding proteins 1,2 and 3 in the bovine species. Domestic Animal Endocrinology, v.22, p.91-102, 2002.

RADCLIFF, R.P.; MCCORMACK, B.L.; CROOKER, B.A.; LUCY, M.C. Growth hormone (GH) binding and expression of GH receptor 1A mRNA in hepatic tissue of periparturient dairy cows. Journal of Dairy Science, v.86, p.3933-3940, 2003 a.

RADCLIFF, R.P.; MCCORMACK, B.L.; CROOKER, B.A.; LUCY, M.C. Plasma hormones and expression of growth hormone receptor and insulin-like growth factor-I mRNA in hepatic tissue of periparturient dairy cows. Journal of Dairy Science, v.86, p.3920-3926, 2003b.

RHOADS, M.L.; MEYER, J.P.; KOLATH, S.J.; LAMBERSON, W.R.; LUCY, M.C. Growth hormone receptor, insulin-like growth factor (IGF)-1, and IGF-binding protein-2 expression in the reproductive tissues of early postpartum dairy cows. Journal of Dairy Science, v.91, p.1802-1813, 2008.

ROBERTS, A.J.; KLINDT, J.; JENKINS, T.G. Effects of varying energy intake and sire breed on duration of postpartum anestrus, insulin like growth factor-1, and growth hormone in mature 
crossbred cows. Journal of Animal Science, v.83, p.1705-1714, 2005.

ROBERTS, A.J.; NUGENT, R.A.; KLINDT, J.; JENKINS, T.G. Circulating insulin-like growth factor I, insulin-like growth factor binding proteins, growth hormone, and resumption of estrus in postpartum cows subjected to dietary energy restriction. Journal of Animal Science, v.75, p.1909-1917, 1997.

SANTOS, J.E.P.; THATCHER, W.W.; CHEBEL, R.C.; CERRI, R.L.; GALVAO, K.N. The effect of embryonic death rates in cattle on the efficacy of estrus synchronization programs. Animal Reproduction Science, v.82-83, p.513-535, 2004.

SAS INSTITUTE. Help and documentation. Version 9.1.3. Cary: SAS Institute, 2002.

SHENG, Z.; RUSSELL, D.F. Comprehensive algorithm for quantitative real-time polymerase chain reaction. Journal of Computational Biology, v.12, p.1045-1062, 2005.

SPICER, L.J.; CHASE JUNIOR, C.C.; RUTTER, L.M. Relationship between serum insulin-like growth factor-I and genotype during the postpartum interval in beef cows. Journal of Animal Science, v.80, p.716-722, 2002.

STAGG, K.; SPICER, L.J.; SREENAN, J.M.; ROCHE, J.F.; DISKIN, M.G. Effect of calf isolation on follicular wave dynamics, gonadotropin and metabolic hormone changes, and interval to first ovulation in beef cows fed either of two energy levels postpartum. Biology of Reproduction, v.59, p.777-783, 1998.

STEVENSON, J.S.; BRITT, J.H. Relationships among luteinizing hormone, estradiol, progesterone, glucocorticoids, milk yield, body weight and postpartum ovarian activity in Holstein cows. Journal of Animal Science, v.48, p.570-577, 1979.

TAYLOR, V.J.; BEEVER, D.E.; BRYANT, M.J.; WATHES, D.C. Metabolic profiles and progesterone cycles in first lactation dairy cows. Theriogenology, v.59, p.1661-1677, 2003.

THISSEN, J.P.; KETELSLEGERS, J.M.; UNDERWOOD, L.E. Nutritional regulation of the insulin-like growth factors. Endocrine Reviews, v.15, p.80-101, 1994.

VELAZQUEZ, M.A.; NEWMAN, M.; CHRISTIE, M.F.; CRIPPS, P.J.; CROWE, M.A.; SMITH, R.F.; DOBSON, H. The usefulness of a single measurement of insulin-like growth factor-1 as a predictor of embryo yield and pregnancy rates in a bovine MOET program. Theriogenology, v.64, p.1977-1994, 2005.

WILLIS, D.S.; MASON, H.D.; WATSON, H.; FRANKS, S. Developmentally regulated responses of human granulosa cells to insulin-like growth factors (IGFs): IGF-I and IGF-II action mediated via the type-I IGF receptor. Journal of Clinical Endocrinology and Metabolism, v.83, p.1256-1259, 1998.

Received on May 18, 2010 and accepted on June 28, 2010 